\title{
Point-of-Care Testing in Sickle Cell Disease
}

\author{
Julie Kanter
}

Additional information is available at the end of the chapter

http://dx.doi.org/10.5772/64862

\begin{abstract}
Sickle cell disease is one of the most common inherited blood disorders. Universal screening and central laboratory diagnostics have improved early identification of affected individuals and helped to reduce childhood mortality in high-resource countries. Additional methods of centralized diagnostics have also been developed in some low resource areas in partnership with private companies, local governments and academic US-based institutions. However, these techniques require expansive infrastructure and government partnership for success. Thus, many individuals living in low-resource settings are often not diagnosed until late childhood when they present with clinical symptoms. In addition, confirmation of disease in affected individuals in the urgent care setting remains limited in both high- and low-resource areas due to the use of batched testing methods. All of the current diagnostic methods rely on advanced laboratory systems and are often prohibitively expensive and time-consuming. To address this need and improve the capacity for timely diagnosis, novel methods for point-of-care testing for sickle cell disease are currently in process.
\end{abstract}

Keywords: point of care, sickle cell, diagnosis

\section{Introduction}

Approximately $5 \%$ of the world's population carries traits for hemoglobin disorder (majority sickle cell disease, thalassemia). The global incidence of sickle cell disease (SCD) is 300,000 births/year of which $90 \%$ are estimated to occur in sub-Saharan African and India, many of whom reside in low-resource areas. In many of these areas, $50-80 \%$ of children die before five years of age [1]. In contrast, a small margin of affected individuals are born in the USA, England, France and other high-resource countries where $98 \%$ of children are living $>18$ years 
of age. In these high-resource countries, early diagnosis remains a key reason for the improved longevity $[2,3]$.

Newborn screening provides an early diagnosis of SCD which has demonstrated efficacy in reducing infant mortality through initiation of penicillin prophylaxis and delivery of care/ education prior to the onset of clinical complications [4, 5]. However, current newborn screening programs are dependent on central laboratories with capabilities to perform costefficient, high-throughput screening [6]. In addition to high-cost laboratory equipment, these programs require complex work-flow including skilled individuals, sample transport and advanced systems of medical care. Additionally, most newborn screening samples are collected at outlying hospitals and are shipped to centralized laboratories where tests are batched and run on a scheduled basis and results are then sent to primary care providers or public health officials to communicate with affected families. Screening is two-tiered starting with testing in the hospital and complementary, confirmatory testing performed at follow-up to confirm the diagnosis (and validate the sample was sent on the correct patient). Thus, all individuals are tested while in the hospital during the newborn period, and the results are often not available for communication until several weeks after discharge. While systems of care exist in many developed countries for communicating these results, these options are not available in other, less resourced areas. Even in some high-resource areas, it can also be difficult to find the newborn and bring them back to the provider for confirmatory testing.

While newborn screening is limited in low-resource areas, many high-resource countries are unable to diagnose and confirm sickle cell disease at the point of care (POC). Similar to tests used during newborn screening, diagnostic tests for SCD are expensive and time consuming. As a result, the testing is often batched and run on specific days with limited availability for diagnosis at the point of care or when the patient presents. While this limitation does not affect most patients who have been previously identified within a health system, the inability to confirm the diagnosis at the point of care can lead to delays in treatment in outside hospitals (where the individual is not usually treated) or inappropriate treatment for an affected individual. Due to the painful nature of this disease, many patients face undue stigmatization for having sickle cell disease. Without "proof" of disease, patients may not be able to receive the care they need in a timely manner. Conversely, there are also anecdotal reports of individuals without SCD who falsely claim to be affected by the condition to receive opioid therapy in the emergency room setting. For those patients not established within a hospital system, a point-of-care test may enhance the ability of acute care physicians to provide appropriate therapy.

Research has clearly demonstrated that the health burden of hemoglobin disorders can be reduced through screening and early diagnosis, prevention and management $[5,7,8]$. While these cost-effective lifesaving strategies/therapies are already known, many are not universally available [9]. Thus, options for enhancing access to early diagnosis include the development of centralized laboratories in low-resource areas and novel point-of-care testing method which remain in development. 


\section{Traditional diagnostic testing in SCD}

The diagnosis of a hemoglobin disorder is usually performed by confirmatory testing in hospital, private or academic laboratories. The majority of current labs in high-resource areas utilize methods of protein chemistry methods such as isoelectric focusing (IEF) or highperformance liquid chromatography (HPLC) and (Sebia) capillary electrophoresis (CE) [10]. Some additional laboratories utilize hemoglobin electrophoresis with either cellulose acetate or citrate agar. Specifically, acid citrate agar is used for conformation of hemoglobin SC disease. See Table 1 for a list of testing methods.

Isoelectric focusing utilizes agarose gels to separate hemoglobin $(\mathrm{Hb})$ fractions and variants based on their isoelectric points [11]. $\mathrm{Hb} \mathrm{A}$ and $\mathrm{Hb} \mathrm{F}$ are clearly resolved by this method. $\mathrm{Hb}$ $\mathrm{C}$ can also be distinguished from $\mathrm{Hb} \mathrm{E}$ and $\mathrm{Hb} \mathrm{O}$, and $\mathrm{Hb} \mathrm{S}$ can be distinguished from $\mathrm{Hb}$.

High-performance liquid chromatography separates hemoglobin in sample by passing them through a column filled with a solid adsorbent material. Specifically, HPLC uses the principles of cation exchange for the separation and determination of the relative percentage of normal and abnormal hemoglobin. Each component in the sample interacts slightly differently with the adsorbent material, causing different flow rates for the different components and leading to the separation of the components as they flow out the column. This is the method used to identify and quantify relative fractions of $\mathrm{Hb} \mathrm{F}, \mathrm{Hb} \mathrm{A} 2, \mathrm{Hb} \mathrm{S}, \mathrm{Hb} \mathrm{C}, \mathrm{Hb}$ Barts and other $\mathrm{Hb}$ variants. HPLC is also used to quantify $\mathrm{Hb} \mathrm{A} 2$ and $\mathrm{Hb}$ F for carrier screening $[12,13]$.

Hemoglobin electrophoresis at alkaline or acidic $\mathrm{pH}$ can be used as a primary or confirmatory method of identification. Electrophoresis separates molecules based on size and charge. Different hemoglobin has a different charge, and according to those charges and the amount, hemoglobin moves at different speeds in the gel whether in alkaline gel or acid gel. This method separates hemoglobin based on the relative mobility of the variant hemoglobin into characteristic bands $[10,14]$.

Novel diagnostic testing in hemoglobinopathies. A variety of novel methods of hemoglobinopathy testing are now available at select laboratories in high-resource areas. These newer techniques expand the analysis and complexity of hemoglobinopathy testing and identification. Techniques include molecular methods of identification, such as the linear array assay, a multiplexed reverse dot blot genotyping method, used to simultaneously test for a panel of common betaglobin variants ( $\mathrm{Hb} \mathrm{S}, \mathrm{C}, \mathrm{E}, \mathrm{D}$ and $\mathrm{O})$, as well as majority (>95\%) of common beta-thalassemia mutations. Another newer method uses multiplex gap PCR assays to detect common alpha thalassemia deletion mutations, alpha globin gene duplications and other globin gene deletions, such as $\mathrm{Hb}$ Lepore and HPFH. Finally, DNA sequence analysis of alpha, beta or gamma globin genes can also be performed to definitively identify unknown point mutations or sequence variation. At present, however, these more advanced techniques remain sequestered in advanced laboratories and are not universally available.

${ }^{1}$ (http://www.rbclab.com/Pages/200/220/116\%20LA/220\%20116.html) 


\begin{tabular}{|c|c|c|c|c|}
\hline Type of test & Method & Results & PRO & $\mathrm{CON}$ \\
\hline \multicolumn{5}{|c|}{ Traditional testing methods } \\
\hline $\begin{array}{l}\text { Isoelectric } \\
\text { focusing }\end{array}$ & $\begin{array}{l}\text { Agarose gels to } \\
\text { separate } \\
\text { hemoglobin based } \\
\text { on isoelectric } \\
\text { points }\end{array}$ & $\begin{array}{l}\mathrm{Hb} \mathrm{A}, \mathrm{Hb} \mathrm{F}, \mathrm{Hb} C, \\
\mathrm{Hb} \mathrm{S}, \mathrm{Hb} \text { E and } \\
\mathrm{Hb} \text { OArab }\end{array}$ & $\begin{array}{l}\text { Reliable, able to } \\
\text { distinguish most types } \\
\text { of sickle cell disease } \\
\text { including compound } \\
\text { heterozygotes }\end{array}$ & $\begin{array}{l}\text { Expensive, requires } \\
\text { skilled technicians, often } \\
\text { batched and run every } \\
\text { few days }\end{array}$ \\
\hline $\begin{array}{l}\text { High-performance } \\
\text { liquid } \\
\text { chromotography }\end{array}$ & $\begin{array}{l}\text { Separates } \\
\text { hemoglobin by } \\
\text { principles of cation } \\
\text { exchange }\end{array}$ & $\begin{array}{l}\text { Identify and quantify } \\
\mathrm{Hb} \mathrm{F}, \mathrm{Hb} \mathrm{A}, \mathrm{Hb} \mathrm{A} 2 \\
\mathrm{Hb} \mathrm{S}, \mathrm{Hb} \mathrm{C}, \mathrm{Hb} \text { Barts } \\
\text { and others }\end{array}$ & $\begin{array}{l}\text { Reliable, able to } \\
\text { distinguish most types } \\
\text { of sickle cell disease, } \\
\text { including compound } \\
\text { heterozygotes }\end{array}$ & $\begin{array}{l}\text { Expensive, requires } \\
\text { skilled technicians, often } \\
\text { batched and run }\end{array}$ \\
\hline $\begin{array}{l}\text { Hemoglobin } \\
\text { electrophoresis }\end{array}$ & $\begin{array}{l}\text { Separates } \mathrm{Hb} \\
\text { based on size and } \\
\text { charge }\end{array}$ & $\begin{array}{l}\text { Identify and quantify } \\
\mathrm{HbF}, \mathrm{Hb} \mathrm{A}, \mathrm{Hb} \mathrm{A} 2, \mathrm{Hb} \\
\mathrm{S}, \mathrm{Hb} \mathrm{C}, \mathrm{Hb} \text { Barts and } \\
\text { others }\end{array}$ & $\begin{array}{l}\text { Reliable, able to } \\
\text { distinguish most types } \\
\text { of sickle cell disease } \\
\text { including compound } \\
\text { heterozygotes }\end{array}$ & $\begin{array}{l}\text { Expensive, requires } \\
\text { skilled technicians, often } \\
\text { batched and run }\end{array}$ \\
\hline \multicolumn{5}{|c|}{ Novel diagnostic testing methods } \\
\hline AMPS & $\begin{array}{l}\text { Density based test } \\
\text { to separate } \mathrm{Hb} \text { in } \\
\text { different density } \\
\text { fluids }\end{array}$ & $\begin{array}{l}\text { Identifies } \mathrm{Hb} \mathrm{S} \text { and } \mathrm{Hb} \\
\text { A }\end{array}$ & $\begin{array}{l}\text { Inexpensive, done at } \\
\text { the point of care }\end{array}$ & $\begin{array}{l}\text { Interpretation is more } \\
\text { difficult, Less reliable } \\
\text { results, difficult to } \\
\text { distinguish HbSC } \\
\text { disease }\end{array}$ \\
\hline $\begin{array}{l}\text { Paper-based } \\
\text { Sickle test }\end{array}$ & $\begin{array}{l}\text { Microfluidic } \\
\text { assessment }\end{array}$ & $\begin{array}{l}\text { Identifies } \mathrm{Hb} \mathrm{S} \text { and } \mathrm{A} \\
\text { and } \mathrm{C} \text { and company } \\
\text { has a separate test } \\
\text { that can identify } \mathrm{Hb} \mathrm{F}\end{array}$ & $\begin{array}{l}\text { Inexpensive, done at } \\
\text { the point of care, reliable } \\
\text { diagnosis of HbSS } \\
\text { disease, easily } \\
\text { performed by } \\
\text { non-skilled } \\
\text { personnel }\end{array}$ & $\begin{array}{l}\text { Requires a scanner for } \\
\text { final results, can be } \\
\text { difficult to distinguish } \\
\mathrm{HbAS} \text { (trait) from HbSC, } \\
\text { test could be altered in } \\
\text { different humidities }\end{array}$ \\
\hline Sickle SCAN & Lateral flow assay & $\begin{array}{l}\text { Distinguishes } \mathrm{Hb} \mathrm{A} \text {, } \\
\mathrm{Hb} \mathrm{S}, \mathrm{Hb} \mathrm{C}\end{array}$ & $\begin{array}{l}\text { Reliably identifies } \mathrm{HbA} \text {, } \\
\mathrm{HbS} \text {, and } \mathrm{HbC} \text {, easily } \\
\text { performed by non- } \\
\text { skilled personnel, easily } \\
\text { interpreted, rapid test } \\
\text { at the point of care }\end{array}$ & $\begin{array}{l}\text { More expensive than the } \\
\text { other point of care tests } \\
\text { above. Does not identify } \\
\text { hemoglobin F. Limit of } \\
\text { detection of } \mathrm{Hb} \text { A is } 2 \%\end{array}$ \\
\hline HemeChip & $\begin{array}{l}\text { Micro- } \\
\text { elecrophoresis } \\
\text { assay }\end{array}$ & $\begin{array}{l}\text { Distinguishes } \mathrm{Hb} \text { F, } \\
\mathrm{S}, \mathrm{C}, \mathrm{A} \text {, and D }\end{array}$ & $\begin{array}{l}\text { Reliable, able to } \\
\text { distinguish most types } \\
\text { of sickle cell disease } \\
\text { including compound } \\
\text { heterozygotes }\end{array}$ & $\begin{array}{l}\text { Requires a skilled } \\
\text { interpretation, web- } \\
\text { based image processing } \\
\text { application for } \\
\text { automated results }\end{array}$ \\
\hline
\end{tabular}

Table 1. Hemoglobinopathy testing methods. 


\section{Centralized laboratory efforts in low-resource settings}

In regions of the world where sickle cell trait and SCD are very prevalent, partnership between private and public organizations and researchers and local hospitals has resulted in impressive newborn screening/diagnostics for SCD. Examples of such efforts include Angola, Uganda and Jamaica.

\subsection{Angola}

Angola's newborn screening program for SCD was born out of the government mandated public health initiative for perinatal HIV screening and a partnership with Chevron. Chevron is one of the leading producers of petroleum in Angola. Thus, Chevron provides support for many Angola-based health initiatives. This initiative was undertaken in partnership with a US academic hospital to assess whether a centralized newborn screening program for SCD was feasible in a low-resource setting. Additional emphasis in this initiative was placed on local training and capacity building for the region. The laboratory was set up in the only pediatric hospital in Angola, and the program was designed to send all collected samples to this location for analysis [15].

For the pilot program in Angola, researchers selected two large maternity hospitals in Luanda as initial sites of blood collection from newborn infants. To enhance local capacity building, obstetrical nurses were trained in the techniques of blood collection and then retrained monthly, and then retrained approximately once a month. All samples were drawn using a heel stick procedure to fill bloodspots on a custom-designed Whatman screening card. Individual cards were distinguished by unique barcodes linked to a database containing necessary demographic information. Additionally, a detachable portion of the card was provided to the mother. Bloodspots were dried and placed in a plastic bag for storage until specimen pickup, as all testing was performed at the central laboratory.

Isoelectric focusing (IEF, RESOLVE® neonatal hemoglobin system, PerkinElmer, Inc.) was used to perform testing of the dried bloodspot samples within one to two days of arrival in the NBS laboratory. Samples were batched for testing (as done in the USA). Once resulted, the samples were scored first by the laboratory technician and the laboratory supervisor subsequently scored each gel independently to ensure accuracy of results. All IEF results with an FAS, FS or other abnormal hemoglobin patterns, or in the rare instance of an indeterminate result, were selected for repeat analysis by capillary electrophoresis (CE).

Attempts were made to contact all families of all newborns with $\mathrm{HbSC}$ or $\mathrm{HbSS}$ results between 6 and 8 weeks of age. Attempted contact was made by telephone. If the family could be reached, infants had repeat samples drawn for confirmatory testing and enrollment in the local sickle cell clinic. However, due to the low-resource area and limited telephone access, $46 \%$ of families of infants (with +tests) could not be contacted highlighting the difficulties of centralized laboratory testing in low-resource areas $[15,16]$. 


\subsection{Uganda}

Similar to Angola, the Ugandan Ministry of Health already had an active program for prevention of mother-to-child transmission of HIV based on identifying and treated infected mother and exposed newborns. It identifies and treats infected mothers and their exposed infants. For this program, dried blood spots are collected from exposed infants at health-care facilities across the country, carried by motorcycle to laboratory hubs at the subdistrict level, and shipped by courier to the Central Public Health Laboratories in the capital. A sickle cell laboratory was initiated within the same central public health laboratories to test for normal and abnormal hemoglobin. Also like Angola, the initiation of the sickle cell NBS program was initiated through a partnership between a US academic center and the local hospital and ministry of health [17-19].

The laboratory methods for sickle cell disease in Uganda were the same as those discussed in Angola. Again, local staff at the Central Public Health Laboratories received on-site training by a technical, US-based team on the study protocol, isoelectric focusing procedures and interpretation of results. Additional sessions and re-teaching sessions were also provided as well as ongoing laboratory support. The system for reporting positive results in Uganda was more advanced than that of Angola. Here, the hemoglobin results were communicated to the collection sites with the existing HIV notification system [20].

\subsection{Jamaica}

Jamaica initiated newborn screening in 1973 with the development of the well-described Jamaican Sickle Cell Cohort Study. In this initial effort, 100,000 consecutive live births were screened at the main Government Maternity Hospital (Victoria Jubilee Hospital, Kingston). Obstetric and labor nurses were trained to collect cord blood specimens, and self-adhesive labels were provided in every labor ward. These labels were duplicated and consecutively numbered so that identical labels were applied to the blood tube and a data card for each patient. The blood tubes were stored at room temperature, collected each morning. These were utilized to form hemolysates which were then used for hemoglobin electrophoresis [21, 22].

Following this initial work, Jamaica initiated a second centralized screening program in 1995 including both the main Government Maternity Hospital in Kingston (Victoria Jubilee Hospital) as well as both the University Hospital of the West Indies, Kingston (added in 1997) and the Spanish Town Hospital (added in 1998) to include $43 \%$ of births in Jamaica. Cord blood samples were collected at birth on a Guthrie card instead of in tubes as done in the initial study. All hemoglobin electrophoresis testing was performed by the newborn screening program at the Sickle Cell Unit (SCU), Tropical Medicine Research Institute, Jamaica. Patient demographics were collected with the Guthrie card and recorded in the newborn screening database. After testing was completed, infants with positive screening results suggestive of a hemoglobinopathy or with an inappropriate specimen or unclear results were notified by letter to come in for confirmatory testing. For those babies who fail to come in, a research nurse found them to encourage parents to bring their infant to the SCU for further testing. 
From 1995 to 2006, 150,803 infants had undergone cord blood screening and approximately 889 infants had phenotype results suggestive of possible SCD in the initial testing [3].

While the efforts described above are successful, they rely on a significant amount of government or partnership support to establish the infrastructure needed for testing patients, confirming the diagnosis and re-identifying/contacting the affected families. Additionally, a large enough patient population is needed within specific areas to justify the cost of this type of infrastructure. Thus, it remains a priority to validate a POC testing device for the diagnosis of SCD.

\section{Point-of-care testing for SCD}

\subsection{Methodology}

To be an effective diagnostic test at the point of care (POC), all testing methods/devices must contain some similar properties. By definition, POC testing requires that testing must occur at or near the site of patient care. The goal of POC is to improve medical and economic outcomes by promoting rapid response and faster therapeutic turnaround time which requires rapid testing in close proximity to the patient. POC tests should also be simple. "Simple" means that the device/test uses unprocessed samples, is easy to read and interpret, does not require medical personnel for testing and includes instructions for confirmatory testing when needed. The test must demonstrate "insignificant risk of erroneous result" through risk analysis which can be overcome for hemoglobinopathy testing through the obligation to perform confirmatory testing. Finally, one of the advantages of diagnostic POC testing is the opportunity for immediate feedback for the patient [23, 24]. A POC gives the tester (or clinician) the capability to interact at the time of testing, taking advantage of the counseling and educational opportunity.

These devices must have high specificity to detect $\mathrm{HbS}$ (including in the presence of hemoglobin F), the capacity to distinguish sickle cell trait (HbAS) from samples with SCD. These point-of-care testing methods for SCD and sickle cell trait must be scalable, portable and easy to use. Results must be available within the same visit/time period for the affected patient (no follow-up required to receive tests results). For low-resource areas, devices need to be low cost, compact, and light weight to enhance portability. Finally, testing must be easy to perform with a simple design and rapid interpretation that does not require complex evaluation (i.e., does not require a medical professional) $[25,26]$.

\subsubsection{POC tests in development}

There are several testing methods and devices currently in development to achieve the aims above. These tests rely in different ways on the pathophysiologic properties of the sickle hemoglobin that differentiate it from other hemoglobin. While this list likely not exhaustive, it includes the current published tests in development. The testing methods are in various stages of evaluation and validation, and many companies and individuals are seeking device 
agency approvals. Current testing methodologies are listed in Table $\mathbf{1}$ and include in the following.

\subsection{Density-based test}

One of the main properties of cells containing hemoglobin $S$ is that these cells sickle upon deoxygenation. The degree of sickling is relative to the quantitative amount of $S$ hemoglobin within the red cell. As cells sickle, this increases their density which allows red blood cells (RBCs) containing hemoglobin to be separated by cell density. Red blood cells in SCD have a specific distribution of cell densities which can be distinguished using Aqueous Multiphase Systems (AMPS). This system includes a combination of polymers and/or surfactants in water than form distinct, immiscible phases which allows the separation of cells based on density. For this testing device, whole blood must be centrifuged and separated into components prior to the red cells being placed in the AMPS solution. To allow for centrifugation in low-resource areas, investigators have identified battery operated mini-centrifuges capable of successfully separating the red cell fragment and allowing for testing. Devices are stable and densities can be tuned to distinguish very small differences $\left(\Delta \rho \sim 0.0005 \mathrm{~g} / \mathrm{cm}^{3}\right)$. However, potential negatives include difficult in interpretation in the field and inability to successfully distinguish hemoglobin SC disease (Figure 1) [27, 28].

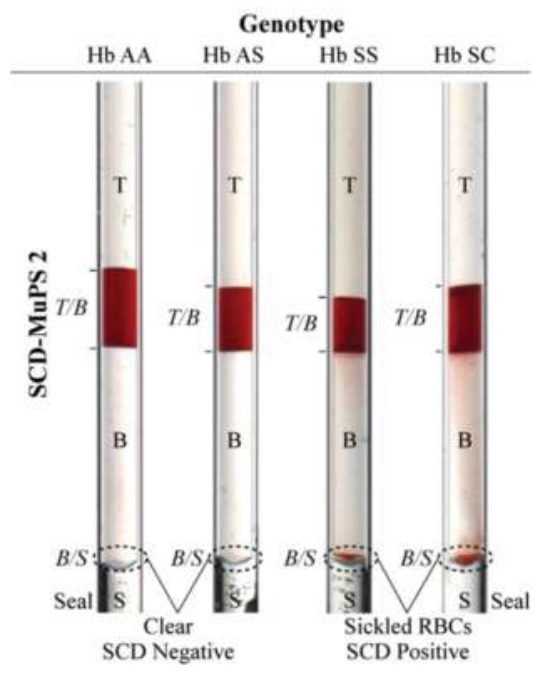

Figure 1. AMPS-based sickle cell disease POC test [27].

\subsection{Microfluidic-paper-based test}

Paper-based testing utilizes similar methodology to conventional hemoglobin solubility assays (e.g. SickleDex ${ }^{\mathrm{TM}}$, SA and ASI test), which have been used routinely by blood banks and clinical laboratories to verify the presence of $\mathrm{HbS}$ in blood samples for many years [10]. When 
deoxygenated, sickle hemoglobin forms polymers, which are more soluble in solution. Specific solubility buffers contain:

1. Saponin irreversibly lyses red blood cells (RBCs) by creating holes in the lipid bilayer that releases hemoglobin into the buffer.

2. Sodium hydrosulfite converts the released hemoglobin into deoxy-Hb that is either soluble $(\mathrm{HbA}, \mathrm{HbE}, \mathrm{HbF}$ or $\mathrm{HbC})$ or insoluble $(\mathrm{HbS})$ in the phosphate buffer.

When these solutions of hemolyzed samples are placed on paper, the delay in transit time caused by the sickle polymers results in a characteristic blood stain pattern which distinguishes normal, sickle cell trait and SCD samples. In other words, paper-based assay identifies the presence of $\mathrm{HbS}$ by measuring the separation of $\mathrm{HbS}$ from non-HbS by differential wicking/ transit of insoluble $\mathrm{Hb} \mathrm{S}$ vs. soluble $\mathrm{Hb}$ in a paper matrix. Blood stain patterns are produced on the chromatography paper based on solubility. However, instead of measuring turbidity (as in Sickledex test), the paper blood stain reflects the amount of polymerized HbS trapped within the paper fibers while the soluble (non-polymerized) hemoglobin continues to spread on the paper. Because hemoglobin is naturally colored, the assay read out uses the red color count in the region of the polymerized hemoglobin and soluble hemoglobin [29].

Testing results (the blood stain) can then be scanned using portable scanners (on a cell phone) to quantify the density of the blood stain and differentiate SCD vs SC trait vs. sickle SC disease. However, this test remains dependent on a low percent of fetal hemoglobin which makes it less ideal in newborn screening. A newer version of the test in development may resolve this complication but results are pending at this time. This device successfully reduces the required blood sample volume, lowering the per-test cost and significantly simplifying the interpretation of results. Sickle cell anemia can be distinguished easily but scanning is required for further hemoglobin differentiating. Scanned results are easy to interpret which makes the test highly adaptable in the non-medical population (Figure 2) [30].
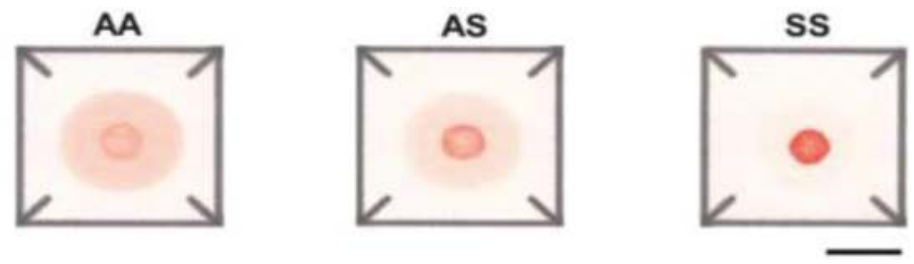

Figure 2. Characteristic blood stain patterns produced by paper-based SCD assay.

\subsection{Lateral flow assays}

Lateral flow assays are simple devices intended to detect the presence (or absence) of a target analyte. For this type of test, the analyte is hemoglobin. Antibodies are utilized to bind to the human alpha globin chain and are conjugated to colored nanoparticles. These antibodies are conjugated to yellow-colored nanoparticles bind the antigen $(\mathrm{Hb})$ as they migrate toward the 
test lines. Conjugated antibodies with bound $\mathrm{Hb}$ (antigen) bind to capture antibodies (polyclonal antibodies for specific hemoglobin S, C, A) on each of three test lines (producing positive result). Nanoparticles without antigens bind to the control line (proof of validity of the testing device) (Figure 3) [32].

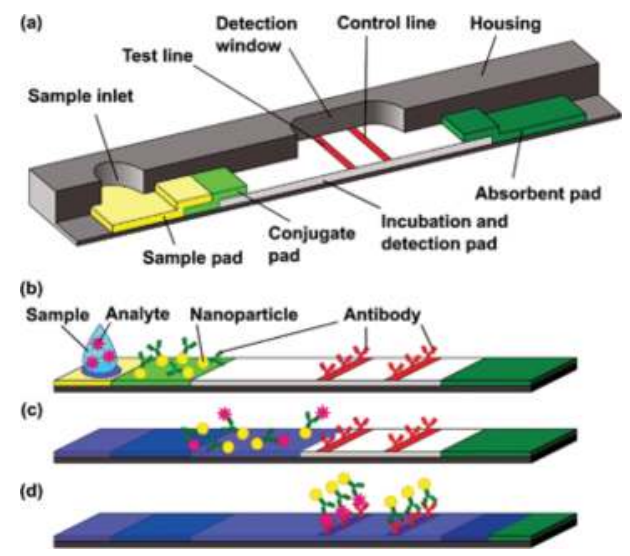

Figure 3. (a-d) Lateral testing method [31].

Current tests in development utilize polyclonal antibodies that can bind to hemoglobin S, C, $\mathrm{A}$ and $\mathrm{F}$. The result is a single test line for each specific hemoglobin (identifying the presence of that particular hemoglobin). Importantly, this type of test is electricity/battery free, can be performed with capillary whole blood that does not require centrifugation and produces rapid results. Because lateral flow tests can demonstrate the result of more than one hemoglobin at a time, these devices can also detect heterozygotes (patients carrying two or more distinctive hemoglobin or patients who have been transfused with a differing hemoglobin).

\subsection{HemeChip (micro-electrophoresis assay)}

The newest published device for point-of-care testing in SCD is a small version of a hemoglobin electrophoresis. Minimal amount of blood (from a capillary stick) is required and placed on a piece of cellulose paper in alkaline buffer. The paper is then inserted into a device (Figure 4) that houses a micro-engineered plastic chip for cellulose acetate electrophoresis and uses a battery powered electric field to separate hemoglobin based on charge as described in standard hemoglobin electrophoresis. The result requires image quantitation using an intensity-based application on a mobile phone image. Results validated against standard EP and HPLC with correlation $>0.96$ for all hemoglobin tested including the ability to distinguish $\mathrm{Hb} F, \mathrm{~S}, \mathrm{C}, \mathrm{A}, \mathrm{D}$. This test utilizes the principles of electrophoresis to detect and distinguish hemoglobin based on the traveling distance from the sample application point and displays quantitative $\%$ hemoglobin fractions. A web-based image processing application for automated and objective quantification of HemeChip results at the POC using cloud computing resources [33]. 

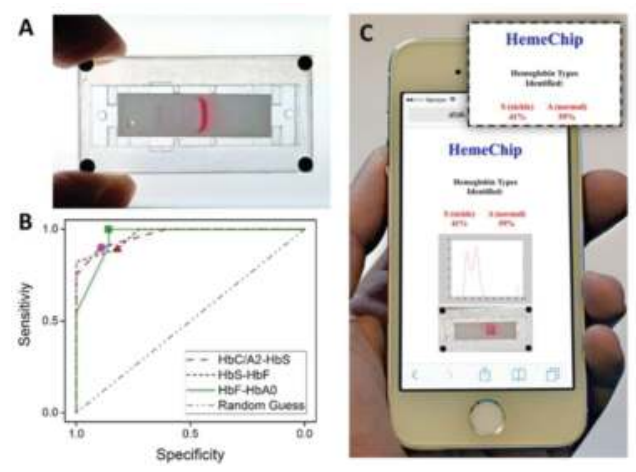

Figure 4. $(\mathrm{a}-\mathrm{c})$ Hemechip [33].

\section{Discussion}

Multiple point-of-care tests are currently in development for the identification of sickle cell disease at the point of care. It is important for confirmatory hematology testing, a multiplex device should be available for clinicians to make proper clinical assessments. As discussed, the device and method must distinguish target hemoglobin from interfering substances in blood that cause false-positive or negative results. It is clear that the pathophysiology of SCD, specifically the point mutations in the genome leading to the hemoglobin expression and the polymer formation that occurs upon cellular dehydration have been well utilized in the design of these testing devices. The optimal testing method will be the device that can produce at the lowest cost, easily utilized in a low-resource setting, with easy-to-interpret results and low false-negative results.

Based on the testing method described above, the lateral flow test is currently the most easily utilized in the field without requiring specialists for interpretation. This test has the capacity to clearly distinguish the majority of hemoglobin within a rapid period of time. However, it is unclear whether lateral flow tests will be cost prohibitive for widespread use. Alternatively, the Hemechip provides an excellent method for sickle cell disease confirmation also easily utilized in point-of-care settings although the interpretation requires additional skill as well as the use of mobile phone and internet access.

\section{Conclusions}

There are significant therapeutic and diagnostic health disparities that exist between SCD and other, inherited and acquired health conditions. Recent literature demonstrates that point-ofcare diagnostics for sickle cell disease are feasible and accurate. Thus, it is hopeful that novel 
point-of-care diagnostics will change the screening paradigm for some areas in which central lab testing is not available.

\section{Author details}

Julie Kanter

Address all correspondence to: kanter@musc.edu

Medical University of South Carolina, Charleston, SC, USA

\section{References}

[1] Piel FB, Hay SI, Gupta S, Weatherall DJ, Williams TN. Global burden of sickle cell anaemia in children under five, 2010-2050: modelling based on demographics, excess mortality, and interventions. PLoS Med. 2013;10(7):e1001484.

[2] Grosse SD, Odame I, Atrash HK, Amendah DD, Piel FB, Williams TN. Sickle cell disease in Africa: a neglected cause of early childhood mortality. Am J Prev Med. 2011;41(6 Suppl. 4):S398-405.

[3] King L, Knight-Madden J, Reid M. Newborn screening for sickle cell disease in Jamaica: a review - past, present and future. West Indian Med J. 2014;63(2):147-150.

[4] Woods GM, Jorgensen JH, Waclawiw MA, et al. Influence of penicillin prophylaxis on antimicrobial resistance in nasopharyngeal S. pneumoniae among children with sickle cell anemia. The ancillary nasopharyngeal culture study of prophylactic penicillin study II. J Pediatr Hematol Oncol. 1997;19(4):327-333.

[5] Platt OS, Brambilla DJ, Rosse WF, et al. Mortality in sickle cell disease. Life expectancy and risk factors for early death. N Engl J Med. 1994;330(23):1639-1644.

[6] Newborn Screening. A blueprint for the future executive summary: newborn screening task force report. Pediatrics. 2000;106(2 Pt 2):386-388.

[7] Blinder MA, Vekeman F, Sasane M, Trahey A, Paley C, Duh MS. Age-related treatment patterns in sickle cell disease patients and the associated sickle cell complications and healthcare costs. Pediatr Blood Cancer. 2013;60(5):828-835.

[8] Gaston M. Screening for sickle cell disease. South Med J. 1974;67(3):257-258.

[9] Piel FB, Patil AP, Howes RE, et al. Global epidemiology of sickle haemoglobin in neonates: a contemporary geostatistical model-based map and population estimates. Lancet. 2013;381(9861):142-151. 
[10] Clarke GM, Higgins TN. Laboratory investigation of hemoglobinopathies and thalassemias: review and update. Clin Chem. 2000;46(8 Pt 2):1284-1290.

[11] Jenkins MA, Ratnaike S. Capillary isoelectric focusing of haemoglobin variants in the clinical laboratory. Clin Chim Acta. 1999;289(1-2):121-132.

[12] Kutlar F, Kutlar A, Huisman TH. Separation of normal and abnormal hemoglobin chains by reversed-phase high-performance liquid chromatography. J Chromatogr. 1986;357(1):147-153.

[13] Kutlar A, Kutlar F, Wilson JB, Headlee MG, Huisman TH. Quantitation of hemoglobin components by high-performance cation-exchange liquid chromatography: its use in diagnosis and in the assessment of cellular distribution of hemoglobin variants. Am J Hematol. 1984;17(1):39-53.

[14] ITANO HA. Interpretation of electrophoretic, solubility and denaturation data in the study of hemoglobin differences. Fed Proc. 1957;16(3):748-756.

[15] McGann PT, Ferris MG, Ramamurthy U, et al. A prospective newborn screening and treatment program for sickle cell anemia in Luanda, Angola. Am J Hematol. 2013;88(12):984-989.

[16] McGann PT, Grosse SD, Santos B, et al. A cost-effectiveness analysis of a pilot neonatal screening program for sickle cell anemia in the Republic of Angola. J Pediatr. 2015;167(6):1314-1319.

[17] Serjeant GR, Ndugwa CM. Sickle cell disease in Uganda: a time for action. East Afr Med J. 2003;80(7):384-387.

[18] Okwi AL, Ocaido M, Byarugaba W, Ndugwa CM, Parkes A. Sickling and solubility tests and the peripheral blood film method for screening for sickle cell disease [corrected]. S Afr Med J. 2009;99(12):887-891.

[19] Ndugwa C, Higgs D, Fisher C, et al. Homozygous sickle cell disease in Uganda and Jamaica a comparison of Bantu and Benin haplotypes. West Indian Med J. 2012;61(7): 684-691.

[20] Rukundo H, Tumwesigye N, Wakwe VC. Screening for HIV I through the regional blood transfusion service in southwest Uganda: the Mbarara experience. Health Transit Rev. 1997;7(Suppl.):101-104.

[21] Serjeant GR. Jamaica, the Caribbean and sickle cell disease. West Indian Med J. 2012;61(4):331-337.

[22] Knight-Madden J, Serjeant GR. Invasive pneumococcal disease in homozygous sickle cell disease: Jamaican experience 1973-1997. J Pediatr. 2001;138(1):65-70.

[23] Collinson PO. The need for a point of care testing: an evidence-based appraisal. Scand J Clin Lab Invest Suppl. 1999;230:67-73. 
[24] Kost GJ. Guidelines for point-of-care testing. Improving patient outcomes. Am J Clin Pathol. 1995;104(4 Suppl. 1):S111-S127.

[25] Alper SL. Harnessing red cell membrane pathophysiology towards point-of-care diagnosis for sickle cell disease. J Physiol. 2013;591(6):1403-1404.

[26] Kost GJ. Optimizing point-of-care testing in clinical systems management. Clin Lab Manage Rev. 1998;12(5):353-363.

[27] Kumar AA, Patton MR, Hennek JW, et al. Density-based separation in multiphase systems provides a simple method to identify sickle cell disease. Proc Natl Acad Sci USA. 2014;111(41):14864-14869.

[28] Kumar AA, Chunda-Liyoka C, Hennek JW, et al. Evaluation of a density-based rapid diagnostic test for sickle cell disease in a clinical setting in Zambia. PLoS One. 2014;9(12):e114540.

[29] Yang X, Kanter J, Piety NZ, Benton MS, Vignes SM, Shevkoplyas SS. A simple, rapid, low-cost diagnostic test for sickle cell disease. Lab Chip. 2013;13(8):1464-1467.

[30] Piety NZ, Yang X, Kanter J, Vignes SM, George A, Shevkoplyas SS. Validation of a lowcost paper-based screening test for sickle cell anemia. PLoS One. 2016;11(1):e0144901.

[31] Mark D, Haeberle S, Roth G, von Stetten F, Zengerle R. Microfluidic lab-on-a-chip platforms: requirements, characteristics and applications. Chem Soc Rev. 2010;39(3): 1153-1182.

[32] Kanter J, Telen MJ, Hoppe C, Roberts CL, Kim JS, Yang X. Validation of a novel point of care testing device for sickle cell disease. BMC Med. 2015;13:225.

[33] Ung R, Alapan Y, Hasan M et al. Point-of-Care Screening for Sickle Cell Disease By a Mobile Micro-Electrophoresis Platform. Blood 2015 126:3379. 